\title{
THE IMPACTS OF CORN IMPORT TARIFF REMOVAL ON ECONOMY, WELFARE AND POVERTY IN INDONESIA: COMPUTABLE GENERAL EQUILIBRIUM APPROACH
}

\author{
Dewi Ermawati ${ }^{1,2^{*}}$, Anindita Ratya ${ }^{1}$, Setiawan Budi ${ }^{1}$, Mustadjab Muslich ${ }^{1}$ \\ ${ }^{1}$ Faculty of Agriculture, University of Brawijaya, Malang, Indonesia \\ ${ }^{2}$ Faculty of Agriculture, University of Tulungagung, Tulungagung, Indonesia
}

*E-mail: ermawati74@gmail.com

\begin{abstract}
This study aims to analyze the impacts of corn import tariff removal on economy, welfare, and poverty in Indonesia. The analisis was conducted using static CGE model based on Social Accounting Matric data and Input Output Table data of 2008 and SUSENAS data. The result shows that corn import tariff removal impacted on economic performances, such as decreasing domestic production, import, and export of involved sectors, yet increasing domestic production of corn sector and other agriculture sectors. The increase of domestic production resulted on the raising of income level on all household classifications in the study, so that it raised the welfare. Import tariff removal impacted on the decrease of poverty level because household welface increased so that it can fulfill their daily needs. The increase of welfare on all clasifications of household impacted on the decrease of poverty, which included the level of poverty, the level of poverty gap, and the level of poverty inequality.
\end{abstract}

\section{KEY WORDS}

General Equilibrium, tariff, import, domestic production, welfare, poverty.

Corn is one of the important food commodities that contributed to the national economy. The food contribution toward GDP in 2010 amounted to $13.93 \%$. Corn as the second source of carbohydrate after rice plays a role in supporting food security, the adequacy of animal feed supplies, and even recently used as a raw material of alternative energy (biofuel). In the diversification of food consumption, corn is used to reduce the dependence on the staple food of rice. Corn also plays a role in the feed industry and other food industries, which requires a greater supply than for direct consumption.

Total consumption of corn during the period of 2008-2012 continued to increase in an average of $5.41 \%$ / year. In 2012, the total consumption reached 20.39 million tons far above the year of 2008 which only reached 16.62 million tons, although consumption in 2012 declined slightly compared to the year of 2011 which reached 20.51 million tons. Total consumption here included direct consumption by households, feed uses, seeds and processing industries (food and non-food). The growth rate of total consumption is faster than production growth rate which only reached $3.21 \%$ / year. In 2012, corn production reached 19.38 million tons, while in 2008 only reached 16.32 million tons. As a result, there is a production deficit since 2010 that reached 1.74 million tons, then surged again in 2011 to 3.28 million tons. In 2012, the deficit declined sharply (due to the rapid increase in production) but still remained substantial at 1.02 million tons (BPS, 2013, Bappenas, 2013).

Various efforts were made to fulfill domestic corn demands due to the production deficit. One way to do this is to import corn. Import volume continued to increase during 2008-2011, especially since 2010 which increased dramatically, from 286,541 tons in 2008 to $1,527,516$ tons in 2010 and to $2,889,174$ tons in 2011 , while in 2012 there was a decrease in imports to $1,889,431$ tons. The decline in import volume in 2012 caused by a significant increase in production amounted to $2,146,858$ tons or $12.46 \%$ compared to 2011 .

Dependency on corn import causes the involving of Indonesia in international trade followed by some accompanying changes. According to the theory of international trade, unimpeded cross-border trade potentially gives benefit to each country through specialization 
of commodity production which is preffered by those countries. However, in fact, the more an economy is liberalized; it does not directly increase the welfare of involved countries. Many studies have shown that trade liberalization can give either advantages or diadvantages, depending on the point of view.

The determination of import tariff will affect on domestic corn price, so that it becomes more expensive. The corn price at the consumer level is the impacts of domestic and imported corn prices. By determining import tariff as government's efforts to protect domestic corn producers, it is expected to improve their welfare. On the other hand, agreements that have been approved by the government to gradually reduce import tariff which will eventually be $0 \%$ will affect the import prices and domestic prices of corn. In this case, corn producers are as the harmed parties. It was stated by Anindita and Reed (2008), if import tariff was removed, there would be a scheme to pay the losses of domestic producers as a result of the increase of welfare in the economy.

The changes of economic environment such as the removal of import tariff will result in the agents in economy (households, government and companies) to be more prosperous or less prosperous. Thus, a study on import tariff removal of corn on economic performance and public welfare and poverty in Indonesia is considered necessary to be conducted in order to obtain an input as an effort of improving the economic performance and welfare of the community. This study aims to find out the impact of corn import tariff toward the performance of domestic production, export, import, welfare and poverty in Indonesia by using computable general equilibrium approach.

\section{THEORETICAL REVIEW}

Import tariff for small country case. Tariff implementation on small country will not affect the term of trade. Country A will produce at a point where the ratio of the domestic marginal cost is equal to the ratio of world exchange in order to maximize the welfare. The following picture shows free market equilibrium. Slope TT is a world price ratio, production is at $P_{1}$, consumption is at $C_{1}$. If Slope TT is tangent indifference curve of $i_{1}$, it means country $A$ exports either clothing or food.

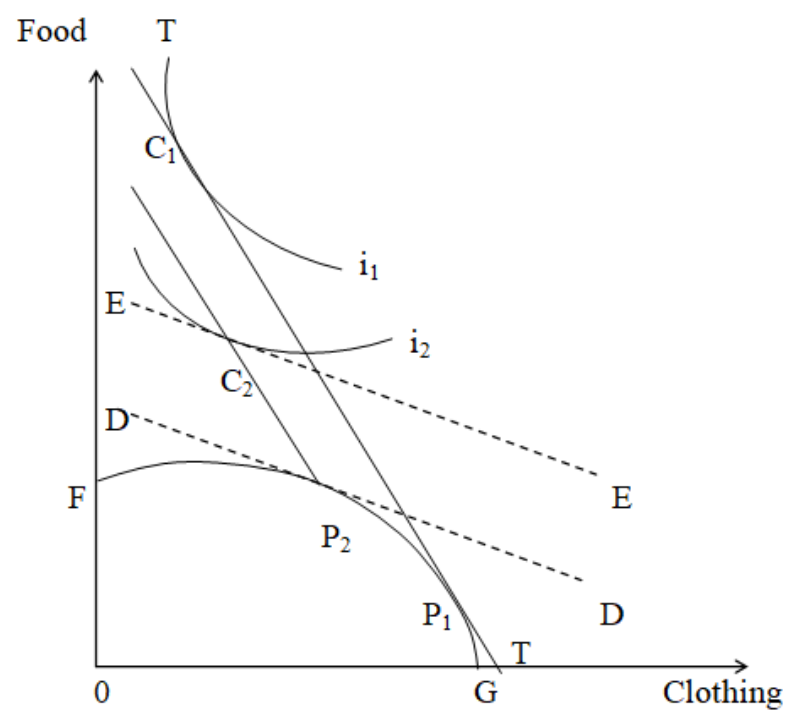

Figure 1 - Import Tariffs of Small Country Case on General Equilibrium Model (Dunn Jr and Mutti, 2000)

Implementation of import tariff in country A will affect on the increase of domestic food. The increase of domestic food prices causes the differences of domestic exchange ratio with the term of trade. It is proven with Slope DD which is domestic exchange ratio is sloping than slope TT which is world exchange ratio. The increase of domestic food prices drives 
producers to increase food productions and decrease clothing productions (at point $\mathrm{P}_{2}$ ), where domestic price line (DD) is tangent the production- possibility curve.

If world prices do not change, then international trade is along $\mathrm{P}_{2} \mathrm{C}_{2}$ (parallel to TT). A new equilibrium is reached when there are two conditions: first, when the EE domestic price line is tangent the indifference curve of i2 which means that the MRS of consumption is equal to the consumer's domestic price ratio; second, when the world price line of $\mathrm{P}_{2} \mathrm{C}_{2}$ crosses the tangent point of indifference curve with $\mathrm{EE}$ domestic price line at $\mathrm{C}_{2}$ point which means domestic price ratio deviates from world price ratio of tariff.

A new equilibrium happens if country $A$ continues to export clothing and import food with amount which is smaller than before the tariff is applied. Tariff enforcement will increase domestic food production, so it will reduce the dependence on food imports. On the other hand, the export of clothing will decrease so it will reduce the welfare shown by the lower indifference curve. Thus tariff policy in the case of small country with a general equilibrium approach will decrease welfare.

Welfare. The consumer's economic environment can either be better or be worse. Economists try to develop tools to measure how cosumers are affected by the changes of its economic environment. The tools used are compensating variation and equivalent variation. Compensating variation and equivalent variation is used for measuring welfare changes by measuring utility changes as a result of policy changes which effects in price changes and real income.

Compensating variation is an income adjustment that can restore consumers' welfare to an early utility level after an economic change (price change). For instance there is a tax increase so prices change from $p^{0}$ to $p^{1}$. Therefore, the minimum amount that consumers are willing to accept is by returning the consumers to the early utility but with a new price in order to run the policy. The equivalent variation is an income adjustment after a price change to reach a new utility (after the change) with the previous price (before the change). Variant (1992) said that equivalent variation used current prices as a basis if there was an income change and its impact on utility. While compensating variation uses the new price as a basis to compensate consumers for price changes (compensation takes place after several changes so that compensating variation uses the new price after the change). Formulated as follows:

$$
\begin{aligned}
& C V=e\left(p^{1}, u^{0}\right)-e\left(p^{0}, u^{0}\right) \\
& E V=e\left(p^{1}, u^{1}\right)-e\left(p^{0}, u^{1}\right)
\end{aligned}
$$

These two methods are a welfare measurement caused by price change. The exact measure which will be used depends on the situation and condition. Compensating variation is used when trying to set some compensation scheme at a new price, but if trying to get a reasonable measure of the willingness to pay then it is better to use an equivalent variation.
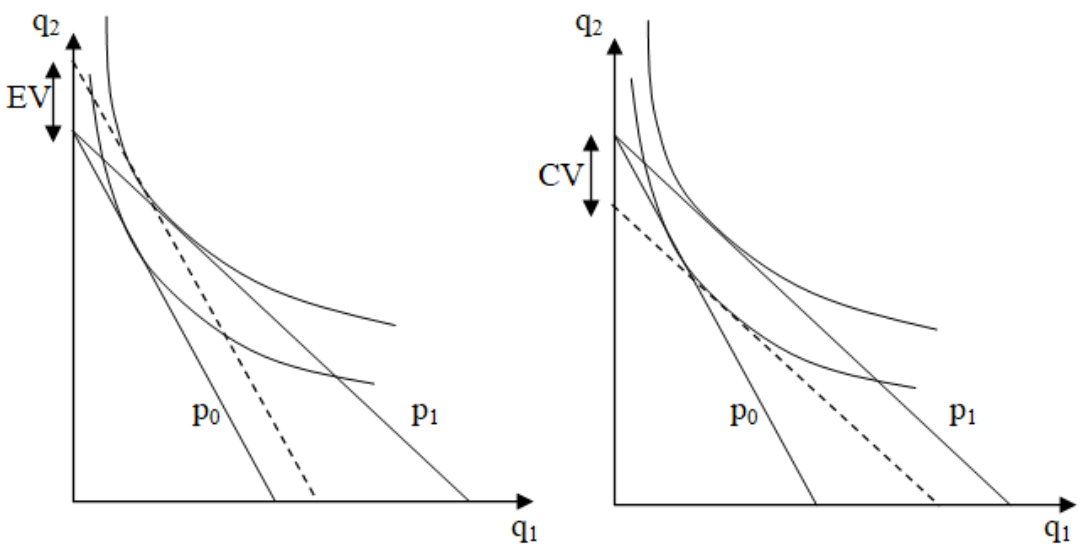

Figure 2 - Compensating Variation (CV) and Equivalent Variation (EV) 
Equivalent variation is widely used as an indicator to measure welfare changes on studies using the CGE model, as a result of trade scenario change. There are two reasons: first, equivalent variation measures income changes at current prices and it facilitates the policymaker to assess the income at current prices rather than some hypothetical price. Second, when comparing more than one proposed policy change, compensating variation using different base prices for each new policy while equivalent variation keeps the base price at the status quo. Thus, equivalent variation is more appropriate for comparison between multiple projects.

Poverty. According to conventional viewpoint especially from monetary aspect, the welfare of household can be measured from obtained income level. Obtained income reflects an authority on commodity used for fulfill their daily needs. If obtained income causes inability of households in fulfiling their basic needs, then it causes the households' well- being deprived. The well- being deprivation is named poverty (World Bank, 2005). Someone or a household is considered poor if there is no income or sufficient comsumptions which places them at the adequate minimimun threshold. Poverty can be related with certain types of consumption, such as house, food, health, and education. Health dimension is often measured directly, for instance by measuring malnutrition or literacy.

Wider approach for well- being (and poverty) focuses on individual ability to be usefull in society. It is said a poor if there is no major ability, such as there is no income or adequate education, or in a poor health, or feeling helpless, or having no political freedom. Thus, poverty is multidimension phenomenon. Efforts in overcoming poverty must be accompanied by other efforts comprehensively, for example higher average income evidently reduces poverty. Therefore it should be accompanied by some actions to empower poor habitants, ensure them towards faced risks or to overcome certain weaknesses (such as the avaibility of schools or inability of health).

\section{MATERIALS AND METHODS OF RESEARCH}

Analysis methods used in this study was static CGE model, where general equilibrium model was developed by Hosoe, et al (2010), and specific model by Lofgren, et al (2002). This static CGE model was used for analyzing the impacts of corn import tariff removal on economic performances (domestic output, export, and import), income, welfare and poverty in Indonesia.

There were some steps had been done in using CGE model, firstly, building basic data which was appropriate with CGE model from I-O table and Social Accounting Matrix (SAM) of 2008. Agregation and dissagresation of sectors from Social Accounting Matrix (SAM) $105 \times 105$ was reduced to matrix $57 \times 57$ with 4 household clasifications, they were farm workers households, agricultural entreprenuer households, rural non-agriculture households and urban non-agriculture households.

In order to build the basic data, these appointed assumptions had to be fulfilled, namely aggrerate demand was equal wih aggregate supply, pure profit amounted zero, cost incurred was equal with revenue. If the asumpsion was fulfilled, the data could be used as basic data of CGE model, and if it was not fulfilled, then it had to be rechecked. In production structure, the relation of input and output had to be known, and the elasticity value of the leontif function, CES, CET obtained from the previous studies. It used assumption of constant return to scale, and product prices was obtained from cost function.

The next step was calibration, modification and integration of elasticity values and parameter with basic data for determining the equilibrium. After finishing, then it was continued with policy simulation to find out the impacts towards economical performance and welfare. Next, comparing the simulation results with starting equilibrium and it was used for the alternative of policy evaluation, as stated in the objective of the study.

In this study, micro simulation was used to analyze poverty, while the CGE analysis result was obtained from the changes of macro household welfare. Thus, it was needed micro data from The National Socio Economic Survey (SUSENAS) as a conversion factor to 
represent the changes of household income. This approach was named Integrated Multihousehold CGE Anaysis (CGE-IMH).

\section{RESULTS AND DISCUSSION}

The Impacts of Corn Import Tariff Removal on Economic Performance. Import tariff is one of the trade barriers determined by government to protect the domestic production from import goods, besides as an income source for the country. The rules of borderless world trade required the involved countries in world trade to decrease, even to remove all kinds of trade barriers, include import tariff. Indonesia as a party of world trade and a member of WTO has to obey the rule by decreasing and removing the import tariff.

The Impacts of Corn Import Tariff Removal on Domestic Production. The decrease and removal of corn import tariff is impacted on the economic sectors. If the corn import tariff is removed, domestic production of corn sector and other agriculture increased, while domestic production of other food crops sectors, poultery and its products, livestock and livestock products, forestry and hunting, fisheries, mining, oil and fat industries, other food, beverage and tobacco industries, other industries and services have decreased.

Table 1 - The Changes of Domestic Production Total due to the Decrease and Removal of Corn Import Tariff

\begin{tabular}{lllll}
\hline Number & Sectors & $\begin{array}{l}\text { Baseline } \\
\text { (Trillion Rupiah) }\end{array}$ & Tariff 3\% & Tariff 0\% \\
\hline 1 & Corn & 405 & 0,494 & 0,741 \\
2 & Other food crops & 563 & $-3,730$ & $-3,375$ \\
3 & Other agricultures & 968 & 1,343 & 1,756 \\
4 & Poultry and its products & 422 & $-2,370$ & $-1,659$ \\
5 & Livestock and livestock products & 593 & $-3,710$ & $-3,204$ \\
6 & Forestry and hunting & 110 & $-0,909$ & $-2,727$ \\
7 & Fishery & 840 & $-2,500$ & $-3,214$ \\
8 & Mining & 1.337 & $-4,712$ & $-5,086$ \\
9 & Oil and fat industries & 2 & $-5,170$ & $-5,550$ \\
10 & Other food, beverage and tobacco industries & 4.288 & $-4,454$ & $-5,924$ \\
11 & Other industries & 6.127 & $-2,203$ & $-2,269$ \\
12 & Services & 14.703 & $-1,503$ & $-1,728$ \\
\hline
\end{tabular}

Source: Data Processing Results (2016).

Import tariff removal causes world price of corn transmitted to domestic market and causes a gap between world price of corn and domestic price of corn. It causes domestic production declines due to the cheaper imported goods prices. In fact, the production of corn and other agriculture increase as a result of the removal of import tariff, although the other sector production decreases. It means that there is another tariff rule implemented which causes the production of both sectors increases. Some studies showed different results with this study. Haryadi (2008) stated that the removal of trade barriers will decrease domestic production. Furthermore, the result study of Pangestika et al. stated that the removal of import tariff will decrease domestic production.

The Impacts of the Increase and Removal of Corn Import Tariff towards Import. The increase and the removal of corn import tariff has positive impacts on import of corn sector, other food crops, other food, beverage and tobacco industries, other industries and services. On the other hand, the increase and removal of corn import tariff will decrease import on other sectors, such as other agriculture, poultery and its products, livestock and livestock products, forestry and hunting, fishery, mining and oil and fat industries. The removal of corn import tariff will increase the demands on imported goods because it is cheaper than domestic prices. Furthermore it is functioned to keep the stocks of corn and other foods in the country so that it will not cause fluctuation in society. By removing corn import tariff, some sectors experience a deficit in import because the needs are fulfilled with the stocks of domestic production. Thus, it does not increase the use of import intermediate input in the 
production prosses. A study by Haryadi (2008) and Pangesty et al. (2015) stated that import will increase by removing the trade barriers.

Table 2 - The Changes of Import Total due to the Decrease and Removal of Corn Import Tariff

\begin{tabular}{lllll}
\hline Number & Sectors & $\begin{array}{l}\text { Baseline } \\
\text { (Trillion Rupiah) }\end{array}$ & Tariff 3\% & Tariff $0 \%$ \\
\hline 1 & Corn & 405 & 2,762 & 2,888 \\
2 & Other food crops & 563 & 2,941 & 2,971 \\
3 & Other agricultures & 968 & $-2,095$ & $-2,089$ \\
4 & Poultry and its products & 422 & $-2,308$ & $-2,231$ \\
5 & Livestock and livestock products & 593 & $-3,636$ & $-2,727$ \\
6 & Forestry and hunting & 110 & 0 & 0 \\
7 & Fishery & 840 & 0 & 0 \\
8 & Mining & 1.337 & $-2,439$ & $-2,256$ \\
9 & Oil and fat industries & 2 & $-3,673$ & $-3,265$ \\
10 & Other food, beverage and tobacco industries & 4.288 & 2,486 & 2,543 \\
11 & Other industries & 6.127 & 1,445 & 1,548 \\
12 & Services & 14.703 & 2,046 & 2,224 \\
\hline
\end{tabular}

Source: Data Processing Results (2016).

The Impacts of the Decrease and Removal of Corn Import Tariff on Export. The decrease and removal of import tariff has positive impacts on the export of corn sectors and other food crops, yet other agriculture sectors, poultery and its products, livestock and livestock products, forestry and hunting, fisheries, mining, other oil and fat industries, other foods, beverages and tobacco industries, other industries and services have decreased as showed in Table 3. It can be seen from the Table 3 that import tariff removal will increase export of several sectors and decrease other sectors in this study. This occurs when reviewed in a general equilibrium framework that composite goods are a combination of imported and domestically produced goods, which will be sold to both domestic and export markets. The size of exports is determined by the total of the composite goods. Exports will be done if domestic needs are fulfill.

Table 3 - The Changes of Export Total due to the Decrease and Removal of Corn Import Tariff

\begin{tabular}{lllll}
\hline Number & Sectors & $\begin{array}{l}\text { Baseline } \\
\text { (Trillion Rupiah) }\end{array}$ & Tariff 3\% & Tariff $0 \%$ \\
\hline 1 & Corn & 405 & 2,600 & 2,824 \\
2 & Other food crops & 563 & 2,655 & 2,755 \\
3 & Other agricultures & 968 & $-4,549$ & $-4,704$ \\
4 & Poultry and its products & 422 & 2,750 & 2,895 \\
5 & Livestock and livestock products & 593 & $-3,211$ & $-4,043$ \\
6 & Forestry and hunting & 110 & $-2,712$ & $-2,650$ \\
7 & Fishery & 840 & $-3,448$ & $-3,103$ \\
8 & Mining & 1.337 & $-2,885$ & $-2,803$ \\
9 & Oil and fat industries & 2 & 0 & 0 \\
10 & Other food, beverage and tobacco industries & 4.288 & $-3,557$ & $-3,482$ \\
11 & Other industries & 6.127 & $-2,737$ & $-2,628$ \\
12 & Services & 14.703 & $-2,168$ & $-2,144$ \\
\hline
\end{tabular}

Source: Data Processing Results (2016).

The Impacts of Corn Import Tariff Removal on Income. The reduction and removal of corn import tariff will increase income of all households (Table 5). This is due to the removal of import tariff which will lower domestic corn prices (to be cheaper) so that it will increase the real income of households as consumers. This finding is in line with the results of the study by Hayati et al (2014) that the removal of import tariff has a positive impact on food security, income and household welfare in Indonesia. The results of this study differ from Pudjiastuti et al (2013) that income of all economic agents will decline with the removal of import tariff.

The Impacts of Corn Import Tariff Removal on Welfare. The reduction and removal of import tariff influences the increase of household welfare in all classes. Farm workers households and rural non-agriculture households experience a higher welfare increase compared to other household groups. This is due to this household class as the owner of 
labor production factor, that the removal of import tariff will increase the real income of households so that their welfare increases.

Table 4 - The Changes of Household Income due to the Decrease and Removal of Corn Import Tariff

\begin{tabular}{lllll}
\hline Number & Households & $\begin{array}{l}\text { Baseline } \\
\text { (Trillion Rupiah) }\end{array}$ & Tariff 3\% & Tariff 0\% \\
\hline 1 & Farm workers households & 2.305 & 2,169 & 2,646 \\
2 & Agricultural entreprenuer households & 2.413 & 2,155 & 2,611 \\
3 & Rural non-agriculture households & 2.709 & 2,289 & 2,436 \\
4 & Urban non-agriculture households & 2.650 & 2,566 & 2,830 \\
5 & Companies & 5.740 & 2,125 & 2,491 \\
\hline
\end{tabular}

Source: Data Processing Results (2016).

Table 5 - The Changes in Household Welfare Due to the Decrease and Removal of Corn Import Tariff

\begin{tabular}{lllll}
\hline Number & Households & $\begin{array}{l}\text { Baseline } \\
\text { (Trillion Rupiah) }\end{array}$ & Tariff 3\% & Tariff 0\% \\
\hline 1 & Farm workers households & 164 & 1.829 & 2.439 \\
2 & Agricultural entreprenuer households & 172 & 0.581 & 1.744 \\
3 & Rural non-agriculture households & 193 & 2.591 & 3.109 \\
4 & Urban non-agriculture households & 189 & 1.058 & 1.587 \\
5 & Companies & 409 & 0.489 & 0.978 \\
\hline
\end{tabular}

Source: Data Processing Results (2016).

The Impacts of Corn Import Tariff Removal on Poverty. The removal of import tarifff affects the change of poverty map of households in Indonesia (Table 6). The calculation results show that with the removal of import tariff will reduce poverty for all household groups. This can be seen from the value of poverty incidence index (P0) in all household classifications of farm workers households, agricultural entreprenuer households, rural nonagriculture households and urban non-agriculture households. When compared with the baseline value, there will be a change of poverty percentage of each household classification of $5.21 \%, 1.61 \%, 7.69 \%$ and $3.42 \%$, respectively.

Table 6 - The Changes of Household Poverty due to Corn Import Tariff Removal

\begin{tabular}{llll}
\hline Number & Households & $\begin{array}{l}\text { Baseline } \\
\text { (Trillion Rupiah) }\end{array}$ & Tariff $0 \%$ \\
& & $\begin{array}{l}\text { Index } \\
\text { (percentage changes from the baseline) }\end{array}$ \\
& Poverty Incidence (P0) & 0,1652 & $0,1566(-5,21)$ \\
1 & Farm workers households & 0,1549 & $0,1524(-1,61)$ \\
2 & Agricultural entreprenuer households & 0,0871 & $0,0804(-7,69)$ \\
3 & Rural non-agriculture households & 0,0614 & $0,0593(-3,42)$ \\
4 & Urban non-agriculture households & & \\
\hline & The depth of poverty (P1) & 0,0324 & $0,0300(-7,41)$ \\
1 & Farm workers households & 0,0310 & $0,0303(-2,26)$ \\
2 & Agricultural entreprenuer households & 0,0161 & $0,0144(-10,56)$ \\
4 & Rural non-agriculture households & 0,0121 & $0,0115(-4,96)$ \\
\hline & Urban non-agriculture households & & \\
2 & Poverty severity (P2) & 0,0095 & $0,0087(-8,42)$ \\
3 & Farm workers households & 0,0093 & $0,0090(-3,23)$ \\
4 & Agricultural entreprenuer households & 0,0046 & $0,0040(-13,04)$ \\
\hline
\end{tabular}

Source: Data Processing Results (2016).

The depth of poverty (P1) and the severity of poverty (P2) decrease with the removal of import tariff proven by the percentage change in index compared to the baseline. A decrease in the depth of poverty means a narrower gap in the income of poor households with a poverty line, whereas a decrease in the severity of poverty indicates less income inequality among households. 


\section{CONCLUSION}

Based on the research of the study, it can be concluded that:

- The removal of corn import tariff is impacted on the economic performance, such as decreasing the domestic production, except corn and other agriculture, decreasing import except corn, other food crops, food industries, other foods, beverage and tobacco industries, other industries and services, and decreasing export except corn and other food crops and poultry.

- The removal of corn import tariff will increase the income of all household classifications, so it iss impacted on the increase of all household clasifications in this study.

- The removal of import tariff will decrease the level of poverty, the level of poverty gap, and the level of poverty inequality.

\section{REFERENCES}

1. Aksoy, M.A. and Bernard M. Hoekman. 2010. Food Prices and Rural Poverty. The International Bank for Reconstruction and Development, World Bank, Washington D.C.

2. Anindita, R. and Reed, M.R. 2008. Bisnis and Perdagangan Internasional. Penerbit Andi.

3. Badan Pusat Statistik. 2010a. Sistem Neraca Sosial Ekonomi Tahun 2008. BPS.

4. Badan Pusat Statistik. 2010b. Tabel Input Output Indonesia Updating 2008. BPS.

5. Buehrer, T and F.D. Mauro. 1995. Computable General equilibrium Model as Tools for Policy Analysis in Development Countries: Some Basic Principles and Empirical Application. Banca D'talia. Rome.

6. Ferrianta, Y. 2012. Dampak Liberalisasi Perdagangan ASEAN-China Free Trade Area terhadap Kinerja Ekonomi Jagung di Indonesia. Disertasi. Universitas Brawijaya. Malang.

7. Haryono, D. 2008. Dampak Industrialisasi Pertanian terhadap Kinerja Sektor Pertanian and Kemiskinan Pedesaan; Model CGE Recursive Dynamic. Disertasi. Institut Pertanian Bogor. Tidak Dipublikasikan.

8. Hayati, M., Anindita R., Hanani, N., and Koestiono, D. 2014. Impact of Food Tariff Decrease in Indonesia. Studia Universtatis Babes Bolyai-Oeconomica.

9. Hulu, E. 1997. Tipologi Model Keseimbangan Umum. Universitas Indonesia. Jakarta.

10. Nicholson, W. 1994. Teori Ekonomi Mikro: Prinsip and Pengembangannya. Raja Grafindo Persada. Jakarta.

11. Nugrahadi, S.I. 2008. Analisis Sumber Pertumbuhan, Keterkaitan and Distribusi Pendapatan Dalam Proses Perubahan Struktural Ekonomi Propinsi Jawa Barat. Disertasi. Institut Pertanian Bogor. Tidak Dipublikasikan.

12. Oktaviani, R. 2001. Dampak Perubahan Kebijakan Fiskal terhadap Kinerja Makro and Sektoral. Bisnis and Ekonomi Politik. 4(4).

13. Pangestuti, V.B., Syafrial and Suhartini. (2015). Simulasi Kebijakan Tarif Impor Jagung terhadap Kinerja Ekonomi Jagung di Indonesia. Habitat 26(2): 100-107

14. Pudjiastuti, A.Q., Anindita, R., Hanani, N., Kaluge, D. 2013. Effect of Sugar Price Increase in Indonesia. Studia UBB, Oeconomica 58(1):28-39

15. Rindayati, W. 2009. Dampak Desentralisasi Terhadap Kemiskinan and Ketahanan Pangan di Wilayah Propinsi Jawa Barat. Disertasi. Institut Pertanian Bogor.

16. Sadoulet, E. and A. de Janvry. 1995. Quantitative Development Analysis. The Johns Hopkins University Press. London.

17. Susilawati, S.H. 2007. Dampak Kebijakan Ekonomi di Sektor Agroindutri terhadap Distribusi Pendapatan and Kemiskinan di Indonesia. Disertasi. Institut Pertanian Bogor.

18. Woods-Early, Y.S. 2006. Sugar Export Price and Import Tariff Reforms: An Environmental Computable General Equilibrium Approach for Developing Countries. Journal of Policy Modelling 22(4): 237-256.

19. Yeah, K.L., J.F. Yanogida and H. Yamauchi. 1994. Evaluation of External Market Effects and Government Intervention in Malaysia's agricultural Sector: A Computable General Equilibrium Framework. Journal of Agricultural Economic Research. 11(2). 